\title{
Current Profile of New HIV Infections Among Adults in Northern Benin in 2016
}

\section{Cossi Angelo Attinsounon ${ }^{1,}{ }^{*}$, Comlan Albert Dovonou ${ }^{2}$, René Kèkè ${ }^{3}$, Cossi Adébayo Alassani ${ }^{2}$, Kouessi Anthelme Agbodandé ${ }^{4}$, Finagnon Armand Wanvoegbe ${ }^{4}$, Angèle Kouanou-Azon ${ }^{4}$, Djimon Marcel Zannou ${ }^{4}$}

${ }^{1}$ Teaching and Research Unit of Infectious Diseases, Faculty of Medicine, University of Parakou, Parakou, Republic of Benin

${ }^{2}$ Service of Internal Medicine, CHUD of Parakou, Parakou, Republic of Benin

${ }^{3}$ National HIV Laboratory of Benin, Cotonou, Parakou, Republic of Benin

${ }^{4}$ Service of Internal Medicine, CNHU-HKM of Cotonou, Parakou, Republic of Benin

\section{Email address:}

acosange@yahoo.fr (C. A. Attinsounon)

${ }^{*}$ Corresponding author

\section{To cite this article:}

Cossi Angelo Attinsounon, Comlan Albert Dovonou, René Kèkè, Cossi Adébayo Alassani, Kouessi Anthelme Agbodandé, Finagnon Armand Wanvoegbe, Angèle Kouanou-Azon, Djimon Marcel Zannou. Current Profile of New HIV Infections Among Adults in Northern Benin in 2016. International Journal of HIV/AIDS Prevention, Education and Behavioural Science. Vol. 3, No. 4, 2017, pp. 36-40. doi: $10.11648 /$ j.ijhpebs.20170304.11

Received: August 11, 2017; Accepted: August 24, 2017; Published: September 26, 2017

\begin{abstract}
Objective: The study aimed to describe the current epidemiological, clinical and immunological profile of newly detected HIV - positive patients in Northern Benin by 2016. Methods: It was a prospective study conducted from May 2 to October 31, 2016 on three main sites of care of people living with HIV (PLHIV) in the department of Borgou in Benin. All new cases of HIV infection have been systematically and comprehensively recruited. Initial epidemiological, clinical and immunological data were collected using a questionnaire. These data were entered and analyzed using the Epi Info 7 software. Results: In total, 185 adults (68 male and 117 female) newly screened HIV positive were included in this study. The middle age was $36.2 \pm 10.9$ years and the sex ratio was 0.6 One hundred and thirty-five patients $(73 \%)$ were between 25 and 50 years old. In terms of the profession, 132 patients $(71.3 \%)$ were engaged in liberal activities (craftmen, traders and retailers). The majority was schooled (113 or $61.1 \%$ ) and resided in urban areas (146 or 79\%). One hundred and sixteen patients lived in couple (62.7\%) with an average monthly income estimated at 70 US Dollars. Clinically, 123 patients $(66.5 \%)$ were in WHO stage III. The body mass index was over $18.5 \mathrm{~kg} / \mathrm{m}^{2}$ in 124 patients $(67 \%)$. The median number of TCD4 lymphocytes was 254.5 cells $/ \mathrm{ml}$ and 25 patients (13.5\%) had a number of CD4 over 500 cells $/ \mathrm{ml}$. HIV1 was really predominant (97.8\%). Most patients (152 or $82.2 \%)$ had been screened for clinical suspicion. Conclusion: HIV infection in Benin remains the prerogative of young, female, educated and poor people. Screening is delayed and hence the need to develop innovative strategies for early HIV testing in Benin.
\end{abstract}

Keywords: Adults, HIV, New Infections, Profile, Borgou, Benin

\section{Introduction}

According to the UNAIDS 2016 report, 36.7 million people were living with HIV among which 25.8 million in sub-Saharan Africa. The number of new infections was 2.1 million, of which 2/3 were in sub-Saharan Africa [1].

In Benin, national HIV prevalence is stable at around $1.2 \%$ since a decade with a concentration of the epidemic within the key populations of sex workers (SW) and men who have sex with men (MSM) [2].

In 2016, 37,637 PLHIV were on antiretroviral therapy (ART), while according to the spectrum projections, Benin would have 65,094 patients requiring ART. Thus, there were approximately 27,457 PLHIV, i.e $42.2 \%$ of patients who 
were unaware of their HIV status, or did not go to treatment sites to get ARV therapy [1]. To improve access to antiretroviral, Benin aligned itself in 2014 with the WHO recommendations of 2013 [3, 4] and is currently in the process of adopting the 2016 guidelines for starting ART in any person tested positive for HIV, regardless of its clinical and immunological status [5]. The implementation of these recommendations was aimed at improving the clinical and immunological status of patients at initiation of ART because several studies have demonstrated the short- and long-term benefit of early initiation of PLHIV to antiretroviral therapy [6-9]. The present study aimed to evaluate the current epidemiological, clinical and immunological profile of new HIV infections detected in Northern Benin in 2016.

\section{Patients and Methods}

\subsection{Study Area and Period}

The study was conducted on the three main sites of care of the PLHIV of the department of Borgou (CHUD Borgou, NGO OSV Jordan and Hospital of Zone of Boko) from May 2 to October $31^{\text {st }}, 2016$.

\subsection{Study Design}

A tricentrique cross-sectional design with prospective data collection was carried out in the study area.

\subsection{Study Population}

Study population was all adults HIV positive received during data collection time in the three centers.

\subsection{Sampling Procedures}

Systematic sampling method was used to select in the study population, all new HIV positive and ART naïve patients after given verbal consent. So, patients under the age of 15 and those who have already been on antiretroviral therapy have been excluded.

\subsection{Data Collection}

All consenting patients were given a thorough clinical examination to complete the pre-established questionnaire. The data collected were socio-demographic (age, sex, marital status, occupation, monthly income, place of resistance) and clinical (discovery, inaugural symptoms and initial clinical stage, weight, height, pathological history and evolutionary diseases). Patients were then referred to the virology laboratory where a blood sample was taken. This sample allowed us to confirm the diagnosis and an initial assessment which includes at least the number of CD4 lymphocytes, complete blood count, transaminases and the serum creatinine. Confirmation of HIV infection was made by a fourth generation Elisa test. All these elements are part of a systematic routine check-up of newly screened HIV-positive people before they are initiated into antiretroviral therapy. The technical range being very limited, some diagnostic (particularly opportunistic infections) mentioned in this work were retained on the basis of syndromic arguments and satisfactory therapeutic tests.

\subsection{Data Analysis}

The data were recorded in the Epi Data 3.1 software and then the descriptive analysis was made using the Epi Info 7 software. Averages and standard deviations were calculated for quantitative variables and frequencies for qualitative variables.

\subsection{Ethical Consideration}

The participating in this study was voluntary. Formel authorization was obtained from the Beninese national HIV program. The data was processed in strict confidentiality and anonymously. Codes were using to identify records at analysis.

\section{Results}

\subsection{Socio-demographic Profile of Patients Newly Diagnosed HIV-Positive}

At the end of this study, 185 newly HIV-positive adults were included. The middle age was $36.2 \pm 10.9$ years and the sex ratio was 0.6 . One hundred and thirty-five patients $(73 \%)$ were between 25 and 50 years of age. The majority of patients were self-employed (132 cases or $71.3 \%$ ), attended school (113 cases or $61.1 \%)$ and lived in urban areas (146 cases or $79 \%)$. One hundred and sixteen patients $(62.7 \%)$ were married or living in a couple and had an average monthly income estimated at 70 US Dollars, or about US $\$ 2.33$ per day. Table 1 presents the sociodemographic data of the respondents.

Table 1. Distribution of 185 new HIV infections in North Benin according to socio-demographic characteristics.

\begin{tabular}{llll}
\hline Variables & Categories & Frequency & \% \\
\hline \multirow{4}{*}{ Sex } & Male & 68 & 36.8 \\
& Female & 117 & 63.2 \\
& Total & 185 & 100 \\
& $15-24$ & 23 & 12.4 \\
& $25-50$ & 135 & 73 \\
& $>50$ & 27 & 14.6 \\
& Total & 185 & 100 \\
Profession & Pupils/Students & 11 & 6 \\
& None & 24 & 13 \\
& Pay & 18 & 9.7 \\
& liberal & 132 & 71.3 \\
& Total & 185 & 100 \\
& Not enrolled & 72 & 38.9 \\
& Schooled & 113 & 61.1 \\
& Total & 185 & 100 \\
Residence & Urban & 146 & 79 \\
& Rural & 39 & 21 \\
& Total & 185 & 100 \\
& Christian & 94 & 50.8 \\
& Muslim & 88 & 47.6 \\
& Traditional & 3 & 1.6 \\
& Total & 185 & 100 \\
\hline \multirow{5}{*}{ Religion } & & & \\
& & &
\end{tabular}




\begin{tabular}{llll}
\hline Variables & Categories & Frequency & \% \\
\hline \multirow{4}{*}{ Marital status } & Married & 116 & 62.7 \\
& Single & 40 & 21.6 \\
& Divorced & 15 & 8.1 \\
& Widows & 14 & 7.6 \\
& Total & 185 & 100 \\
& Alcohol addiction & 48 & 25.9 \\
& Tobacco & 6 & 3.2 \\
& Alcohol + tobacco & 12 & 6.5 \\
& Neither alcohol nor tobacco & 119 & 64.3 \\
& Total & 185 & 100 \\
& Beninese & 170 & 91.9 \\
& other & 15 & 8.1 \\
& Total & 185 & 100 \\
\hline
\end{tabular}

\subsection{Initial Clinical, Nutritional and Immunological Status of Patients}

Clinically, 20 patients $(10.8 \%)$ were at stage IV WHO, 123 patients $(66.5 \%)$ at stage III WHO, 19 patients $(10.3 \%)$ at stage II and 23 patients $(12.4 \%)$ at stage I. The nutritional status of the patients surveyed was assessed on the basis of body mass index and it was noted that 61 patients $(33 \%)$ were thin, 98 had normal nutritional status $(52.9 \%), 19$ were obese $(10.3 \%)$ and seven were overweight (3.8\%). Long-term fever (121 cases or $65.4 \%)$, weight loss (114 cases or $61.6 \%)$, persistent diarrhea (84 cases or $45.4 \%$ ) and chronic cough ( 48 cases or $25.9 \%$ ) were the four main symptoms found (Figure 1).

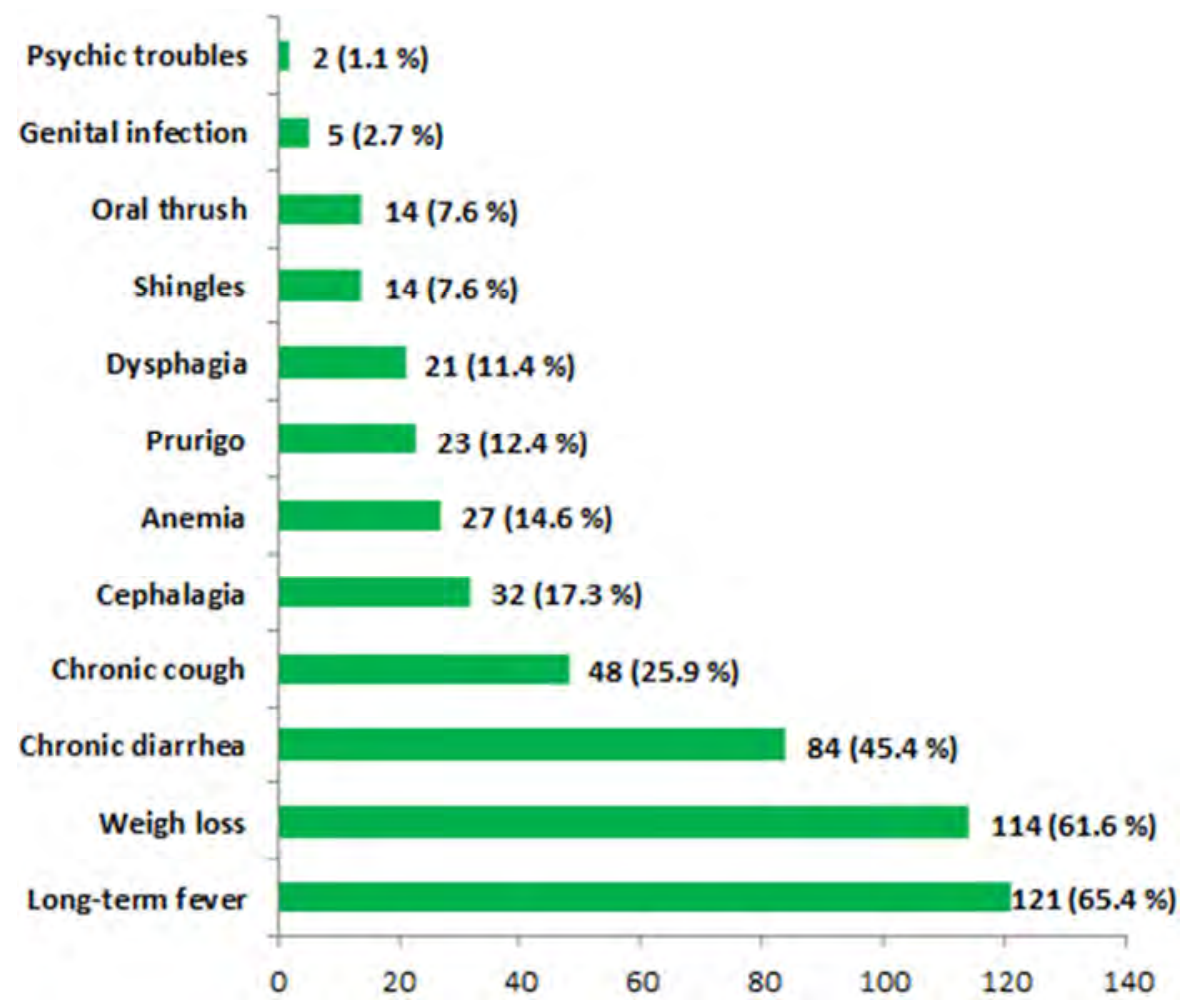

Figure 1. Distribution of the 185 new cases of HIV infection in Northern Benin according to the symptoms presented at the initial examination in 2016.

Bacterial infections (122 cases or $65.9 \%)$, mainly tuberculosis (96 cases or $51.9 \%$ ) and salmonellosis (19 cases or $10.3 \%$ ) were the most frequent, followed by parasitic infections (109 cases or $58.9 \%$ ), mycotic ( 80 cases or $43.2 \%$ ) and viral (58 cases or $31.4 \%$ ). On the immunological level, the median number of TCD4 lymphocytes was 254.5 cells $/ \mathrm{ml}$ with extremes of 5 and 1,031 cells $/ \mathrm{ml}$. The initial number of CD4 was less than 200 cells $/ \mathrm{ml}$ in 98 patients $(53 \%)$, with $200-500$ cells $/ \mathrm{ml}$ in 62 patients $(33.5 \%)$ and more than 500 cells $/ \mathrm{ml}$ in 25 patients $(13.5 \%)$.

\subsection{Circumstances of Discovery and Serotype of HIV}

HIV1 was really predominant (181 cases or 97.8\%) and there were four cases of HIV2 (2.2\%).

Depending on the screening circumstance, 152 cases $(82.2 \%)$ were screened on clinical suspicion, 30 cases $(16.2 \%)$ were voluntary, and three cases (1.6\%) were screened during prenatal consultations.

\section{Discussion}

\subsection{Socio-demographic Profile of Patients Newly Diagnosed HIV-Positive}

The current socio-demographic profile of people newly infected with HIV in Northern Benin is largely comparable to that described in most of the studies conducted in subSaharan Africa. AIDS remains in Benin and sub-Saharan Africa a disease affecting mostly young people, predominantly female, resident in urban areas and having low purchasing power [9-12]. It emerges from this study that preventive measures should be given priority to young girls in urban areas, with low incomes and in liberal professions such as hairdressing, sewing, resale or small business. The profile described above is compatible with that of sex workers; the majority of whom practice clandestinely and 
sometimes live in a couple.

\subsection{Circumstances of Discovery and Initial Clinical and Immunological Status of Patients}

In $82.2 \%$ of cases, our respondents were screened because they had clinical manifestations related to AIDS. They were classified in stage III or IV WHO in $77.3 \%$ of the cases which indicates a late screening. This is the finding in most studies in the sub-region [9-11, 13, 14]. Indeed, the screening strategy at the initiation of caregivers recommended by the WHO is not applied leaving room for screening on clinical suspicion. Therefore, most patients integrate HIV care programs into the AIDS stage with multiple opportunistic infections. In our study, bacterial and parasitic opportunistic infections were the most frequent and were manifested by long-term fever, weight loss, diarrhea and chronic cough. In fact, they were mainly tuberculosis, the first opportunistic bacterial infection in PHAs in sub-Saharan Africa $[15,16]$ and opportunistic digestive parasites [17] whose diagnosis is not always possible in our context where technical conditions are not often available. Effective integration of HIV and tuberculosis programs is therefore necessary to ensure an efficient response to both diseases $[15,18,19]$.

This study therefore advocates concrete actions to detect people living with HIV at an earlier stage. Integration of HIV testing in community areas coupled with a referral system through the network of civil society organizations, with the involvement of community outreach workers and peer educators identified by sector of activity, could help to facilitate the accessible and early screening.

\section{Conclusion and Recommendation}

In Benin, HIV infection remains the prerogative of young people, mostly female, with low purchasing power. The screening is too late, because performed on clinical suspicion which remains the main circumstance of the discovery of the infection. It is therefore urgent to develop innovative strategies as HIV self-screening and community-based screening, for the early detection of HIV in Benin as a guarantee of early access to antiretroviral treatment.

\section{Limitation}

The main limit of this study was the poverty of the technical platform limiting certain diagnoses. This issue may raise possibility of information bias. It would also be desirable to extend the study period to one year in order to avoid possible influences of the season on the use of health centers.

\section{References}

[1] ONUSIDA (2016) Global AIDS update. UNAIDS pp. 16 http://www.unaids.org/sites/default/files/media_asset/globalAIDS-update-2016_en.pdf. Consulted at 11/02/17.
[2] Comité National de Lutte contre le SIDA (2016). Rapport de suivi de la déclaration de politique sur le VIH/SIDA au Bénin. CNLS-Bénin. pp. 22.

[3] OMS (2013) Lignes directrices unifiées sur l'utilisation des antirétroviraux pour le traitement et la prévention de l'infection à VIH. Résumé des principales caractéristiques et recommandations.

www.who.int/hiv/pub/guidelines/arv2013/15facts/fr.

Consulted at 11/02/17.

[4] Programme National de Lutte contre le Sida (2014) Politique, normes et procédures pour la prise en charge des personnes vivant avec le VIH au Bénin. PNLS-Bénin. pp. 41.

[5] OMS (2016) Consolidated guidelines on the use of antiretroviral drugs for treating and preventing HIV infection. Recommendations for a public health approach - Second edition. pp. 480. http://www.who.int/hiv/pub/arv/arv-2016/en/. Consulted at 11/02/17.

[6] Eaton JW, Johnson LF, Salomon JA, Bärnighausen T, Bendavid E, Bershteyn A, Bloom DE, Cambiano V, Fraser C, Hontelez JA, Humair S, Klein DJ, Long EF, Phillips AN, Pretorius C, Stover J, Wenger EA, Williams BG, Hallett TB (2012) HIV treatment as prevention: systematic comparison of mathematical models of the potential impact of antiretroviral therapy on HIV incidence in South Africa. PLoS Med. 9(7): e1001245.

[7] Govindasamy D, Meghij J, Negussi EK, Baggaley RC, Ford $\mathrm{N}$, and Kranzer K (2014) Interventions to improve or facilitate linkage to or retention in pre-ART (HIV) care and initiation of ART in low- and middle-income settings - a systematic review. J Int AIDS Soc. 17(1): 19032.

[8] Herout S, Mandorfer M, Breitenecker F, Reiberger T, Grabmeier-Pfistershammer K, Rieger A, Aichelburg MC (2016) Impact of early initiation of antiretroviral therapy in patients with acute HIV Infection in Vienna, Austria. PLoS One. 11(4): e0152910.

[9] IeDea and ART Cohort Collaborations, Avila D, Althoff KN, Mugglin C, Wools-Kaloustian K, Koller M, Dabis F, Nash D, Gsponer T, Sungkanuparph S, McGowan C, May M, Cooper D, Chimbetete C, Wolff M, Collier A, et al. (2014) Immunodeficiency at the start of combination antiretroviral therapy in low-, middle-, and high-income countries. J Acquir Immune Defic Syndr. 65(1): e8-16.

[10] Déguénonvo LF, Manga NM, Diop SA, Dia Badiane M, Seydi M, N'dour CT, Soumaré M, Diop BM, Sow PS (2011) Profil actuel des patients infectés par le VIH hospitalisés à Dakar (Sénégal). Bull. Soc. Pathol. Exot. 104: 366-370.

[11] Koné MC, Cissoko Y, Diallo MS, Traoré BA, Mallé KK (2013) Données épidémiologiques, cliniques et thérapeutiques des patients infectés par le VIH sous traitement antirétroviral à l'hôpital de Ségou au Mali (2004-2011). Bull. Soc. Pathol. Exot. 106: 176-179.

[12] Kra O, Aba YT, Ouatara B, Abouo F, Tanon KA, Eholié S, Bissagnené E (2013) Profil clinicobiologique, thérapeutique et évolutif des patients infectés par le VIH hospitalisés au service des maladies infectieuses et tropicales d'Abidjan (Côte d'Ivoire). Bull. Soc. Pathol. Exot. 106(1): 37 - 42.

[13] Koy T, Mukumbi H, Malandala GLM, Donnen P, WilmetDramaix M (2014) Profil comparatif et évolutif des personnes infectées par le virus de l'immunodéficience humaine traitées aux antirétroviraux à Kinshasa, République Démocratique du Congo. Pan African Medical Journal. 19: 388. 
[14] Nash D, Tymejczyk O, Gadisa T, Gorrell Kulkarni S, Hoffman S, Yigzaw M, Elul B, Remien RH, Lahuerta M, Daba S, El Sadr W, and Melaku Z (2016) Factors associated with initiation of antiretroviral therapy in the advanced stages of HIV infection in six Ethiopian HIV clinics, 2012 to 2013. J Int AIDS Soc. 19(1): 20637.

[15] Daftary A, Padayatchi N (2013) Integrating patients' perspectives into integrated TB/HIV healthcare. Int J Tuberc Lung Dis. 17(4): 546-551.

[16] van Schalkwyk C, Variava E, Shapiro AE, Rakgokong M, Masonoke K, Lebina L, Welte A, Martinson N (2014) Incidence of TB and HIV in prospectively followed household contacts of TB index patients in South Africa. PLoS One. 9(4): e95372.
[17] Nsagha DS, Njunda AL, Assob NJC, Ayima CW, Tanue EA, Kibu OD, Kwenti TE (2016) Intestinal parasitic infections in relation to $\mathrm{CD}^{+} \mathrm{T}$ cell counts and diarrhea in HIV/AIDS patients with or without antiretroviral therapy in Cameroon. BMC Infect Dis. 16: 9.

[18] Kerschberger B, Hilderbrand K, Boulle AM, Coetzee D, Goemaere E, De Azevedo V, Van Cutsem G (2012) The effect of complete integration of HIV and TB services on time to initiation of antiretroviral therapy: a before-after study. PLoS One. 7(10): e46988.

[19] Rie AV, Clouse K, Hanrahan C, Selibas K, Sanne I, Williams S, Kim P, Bassett J (2014) High uptake of systematic HIV counseling and testing and TB symptom screening at a primary care clinic in South Africa. PLoS One 9(9): e105428. 